\title{
Numerical modeling of rebar buckling in reinforced concrete members using truss analogy
}

\author{
Betonarme elemanlarda donatı burkulmasının kafes kiriş analojisi ile \\ sayısal modellenmesi
}

\author{
Sadık Can GIRGIN ${ }^{1 *}$ iD \\ 1İnşaat Mühendisliği Bölümü, Mühendislik Fakültesi, Dokuz Eylül Üniversitesi, İzmir, Türkiye. \\ sadik.girgin@deu.edu.tr
}

Geliș Tarihi/Received: 09.11.2016, Kabul Tarihi/Accepted: 06.05.2017

* Yazıșilan yazar/Corresponding author

doi: $10.5505 /$ pajes.2017.13549 Araștırma Makalesi/Research Article

\begin{abstract}
Reinforced concrete $(R C)$ structures in earthquake prone regions are designed to achieve the seismic performance objectives. In end regions of RC members, longitudinal reinforcing bars may develop buckling due to high compressive strains under reversed cyclic loadings. The performance based assessment for $R C$ structures should rely on analytical models which can account for the effect of rebar buckling on the nonlinear response. This study extends a previously proposed nonlinear truss modeling approach for modeling RC elements whose response is affected by rebar buckling. Nonlinear truss model includes diagonal truss elements accounting for biaxial effects in compression and tension stiffening for concrete elements in the horizontal and vertical directions. The truss elements representing reinforcing steel are provided with a uniaxial material model which can explicitly account for inelastic buckling and fracture of rebars. The modeling approach is validated with experimental test results on one $\mathrm{RC}$ beam considering mesh size effects on the response. Numerical model computed strength degradation in moment-drift ratio response of the beam in accordance with the experimental results.
\end{abstract}

Keywords: Nonlinear truss model, Rebar buckling, Reinforced concrete

\section{Introduction}

Modern reinforced concrete (RC) frames are designed to develop inelastic flexural deformations in their end regions. During earthquakes, longitudinal reinforcing bars of frame members have a tendency for buckling resulting from high compressive strains. Reinforcing bar buckling may occur due to the interaction between rebars and concrete in that cover concrete provides initial restraint till crushing while core concrete exerts outward pressure on rebars [1]. Experimental studies revealed that compressive behavior of reinforcing bars are mainly affected by buckling length [2]-[4]. The occurrence of longitudinal bar buckling in inelastic regions can crucially affect the ductility of RC members.

Analytical prediction of ductility of RC elements can be overestimated if buckling of rebars is not accounted for in the numerical models. Numerical simulation modeling approaches for RC structures can be categorized as concentrated plasticity, distributed plasticity, finite element and truss-based models.

Zong et al. [5] conducted 3-D finite element simulations for circular RC columns and developed beam-on-springs model by isolating reinforcing bars. Massone and Lopez [6] proposed a concentrated plasticity model with four plastic hinges accounting for initial imperfections. A hybrid finite element
Öz

Deprem kușağında yer alan bölgelerdeki betonarme yapılar, sismik performans hedeflerini sağlamak üzere tasarlanır. Betonarme elemanların uç bölgelerinde, boyuna donatılarda burkulmaya bağlı yanal șekil değistirmeler gelisebilir. Betonarme yapıların performansa dayalı değerlendirilmesi doğrusal olmayan davranış üzerinde donatı burkulma etkilerini hesaba katan analitik modellere dayalı olmalıdır. Bu çalıșmada, literatürde yer alan doğrusal olmayan kafes modelleme yaklaşımı donatı burkulmasından etkilenen betonarme elemanlar için genișletilmiștir. Doğrusal olmayan kafes kiriș modeli basınç etkisi altında diyagonal elemanlarda çift eksenli etkileri, yatay ve düşey beton elemanlarda ise çekme güclenmesini dikkate almaktadır. Donatıları temsil eden kafes elemanlar, elastik olmayan burkulma ve kopmayı açık șekilde hesaba katan tek eksenli bir malzeme modeli ile tanımlanmıștır. Sunulan çalışmada, modelleme yaklaşımı bir betonarme kiriş testi sonuçları ile doğrulanmıș ve sonlu eleman boyut değișiminin modeldeki etkileri arastırılmıstır. Sayısal model moment-ötelenme oranı ilişkisindeki dayanım azalmasını deney sonuçlarıla uyumlu olarak hesaplamiștır.

Anahtar Kelimeler: Doğrusal olmayan kafes model, Donatı burkulması, Betonarme

model consisting distributed plasticity and finite element models predict reinforcement buckling was proposed by Feng et al. [7]. Kashani et al. [8] studied modeling rebar buckling in RC columns using nonlinear fiber-based elements and concluded that material models are needed considering inelastic buckling and fracture of rebars. Recently, a uniaxial material model has been developed by Kim and Koutromanos [9] capable of representing rebar buckling and fracture enhancing the material model proposed by Dodd and RestrepoPosada [10].

Truss-based models have been studied for design and analysis of RC members subjected to shear, flexure and axial forces [11]-[13]. Panagiotou et al. [14] presented a nonlinear cyclic truss modeling approach for RC walls including flexure-shear interaction with mesh size effects and biaxial effects for diagonal elements in compression. The model with finer mesh computed smaller peak applied force [14]. Lu and Panagiotou [15] developed a nonlinear beam-truss modeling approach for modeling RC walls. Moharrami et al. [16] enhanced the truss model for analysis of shear-critical RC columns including the contribution of aggregate interlock effects. Lu et al. [17] presented a 3-D truss model for structures including walls and slabs with mesh refinement in the bottom story. 
This study extends truss-based modeling approaches for modeling RC members with significant reinforcing bar buckling. Reinforcing bars susceptible to buckling are modeled explicitly with a uniaxial material model proposed by Kim and Koutromanos accounting for inelastic buckling and fracture [9]. Moreover, the model considers strain penetration effects resulted by longitudinal reinforcement slip from anchorage of beam to foundation. Experimental cyclic response of one RC beam with significant buckling of reinforcing bars is studied by using truss-based model with mesh size effects on the response.

\section{Nonlinear truss modeling approach}

Truss modeling approach provides an effective tool for analyzing stress flow in reinforced concrete members. A truss model is idealized by using principal stress trajectories obtained from linear analysis [1]. Nonlinear truss model is established by assignment of location of horizontal elements including longitudinal rebars for beams and diagonal element angles [16]. Truss model herein uses elements in the horizontal, vertical and diagonal directions representing steel reinforcement and concrete areas. Nonlinear concrete trusses for diagonal elements account for biaxial effects on the compression behavior while tension stiffening effects are considered in the vertical and horizontal directions. A cantilever beam, geometry and structural idealization by using truss model is shown in Figure 1. Figure 1(b) shows the truss model where $H_{m}$ is the distance between top and bottom longitudinal rebars, $L$ is shear span and $s$ is stirrup spacing. Anchorage deformations are accounted for using additional truss elements within the length $\left(L_{s p}\right)$ in the truss model. $L_{s p}$ is calculated as,

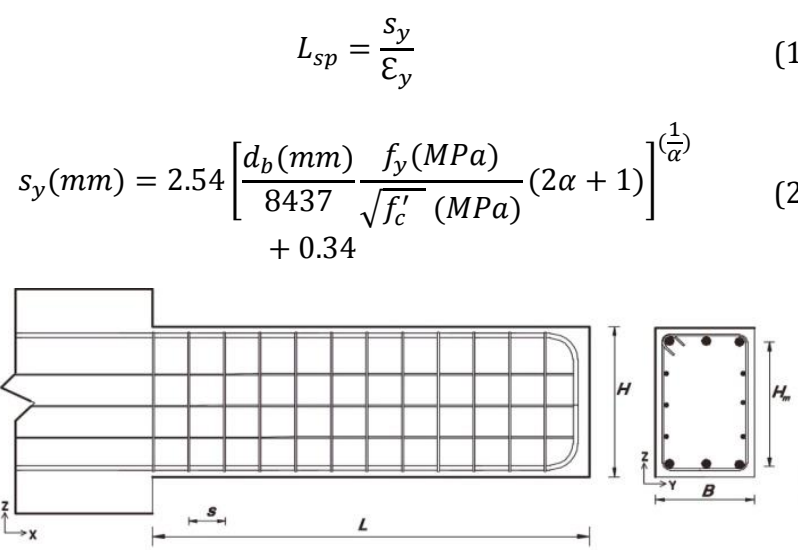

(a)

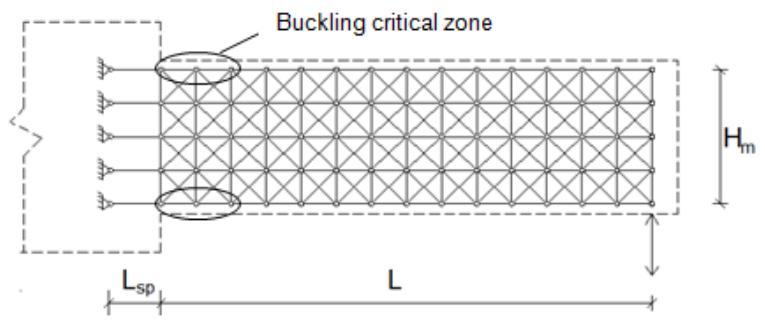

(b)

Figure 1: (a): Details of a cantilever beam, (b): Nonlinear truss model.

Where $s_{y}$ is total slip at the yield, $d_{b}$ is rebar diameter, $f_{y}$ yield strength of rebar, $f_{c}{ }^{\prime}$ is compressive strength and $\alpha$ is parameter for local bond-slip [18]. Concrete truss elements have zero- tensile strength within the region with larger areas than the horizontal elements to account for stiffness of reaction block.

Vertical and horizontal truss elements were placed and their effective areas are depicted in Figure 2(a-c) where $s$ and $h$ are spacing between vertical and horizontal elements, respectively. Figure 2(d) shows the diagonal cross-section and the area of diagonal elements is the product of beam width $(B)$ and effective width $\left(b_{\text {eff }}\right)$.
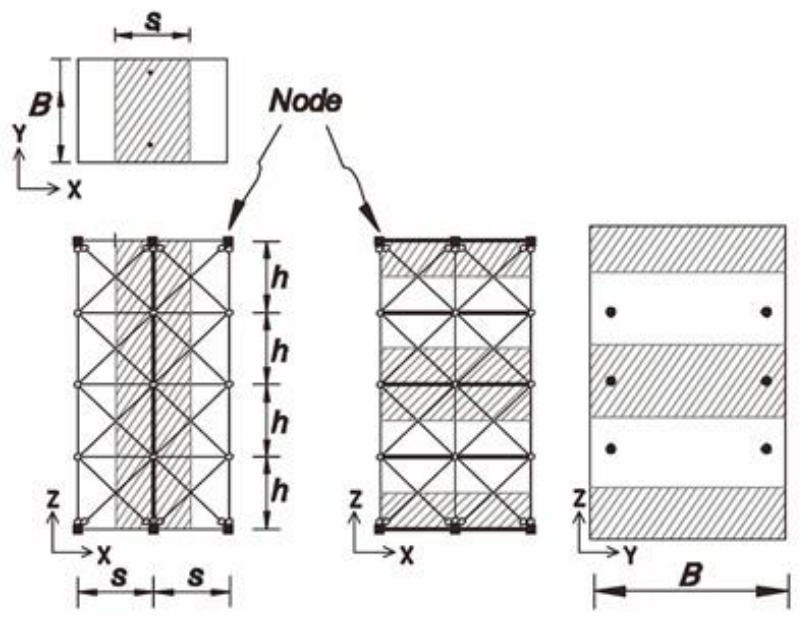

(a): Vertical truss elements, (b): Horizontal truss elements.
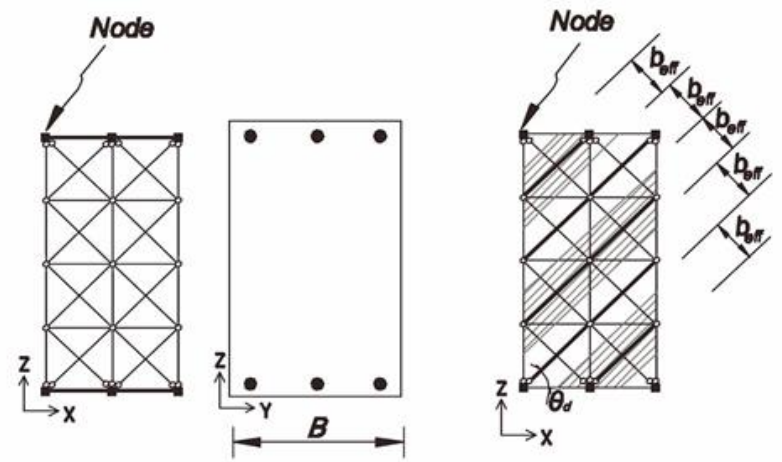

(c): Horizontal steel truss elements, (d): Diagonal truss elements.

Figure 2: Concrete and steel truss section effective areas for truss model [19].

\section{Material models}

\subsection{Reinforcing steel material model}

Kim and Koutromanos [9] enhanced the material model proposed by Dodd and Restrepo-Posada [10] by adding a noniterative stress update procedure. Unlike the existing material model using nonlinear functions, proposed material model uses NURBS (nonuniform rational b-splines) curves between the points on the reversal branches.

The enhanced material model considers the effect of reinforcing bar buckling and fracture. A dimensionless slenderness ratio $\left(\boldsymbol{L}_{\boldsymbol{b}} / \boldsymbol{D}\right)$ is assigned in a derived equation for stresses of a beam with rotational restraints where $\boldsymbol{L}_{\boldsymbol{b}}$ is buckling length and $\boldsymbol{D}$ is rebar diameter [9]. Buckling length $\left(\boldsymbol{L}_{\boldsymbol{b}}\right)$ and buckling mode $(\boldsymbol{n})$ of longitudinal rebars are calculated based on the procedure by Dhakal and Maekawa [20]. After onset of buckling, a coefficient accounting for 
reduction in bar resistance based on buckling was introduced in the enhanced material model in the core hysteretic law to multiply the stresses [9]. Monotonic stress-strain relationship of the material model is given in Figure 3 in the engineering stress-strain space, where $\boldsymbol{f}_{\boldsymbol{y}}, \boldsymbol{\varepsilon}_{\boldsymbol{y}} ; \boldsymbol{f}_{\boldsymbol{s h} \mathbf{1}}, \boldsymbol{\varepsilon}_{\boldsymbol{s h} \mathbf{1}}$ and $\boldsymbol{f}_{\boldsymbol{u}}, \boldsymbol{\varepsilon}_{\boldsymbol{s} u}$ are yield, intermediate and ultimate stresses and strains, respectively.

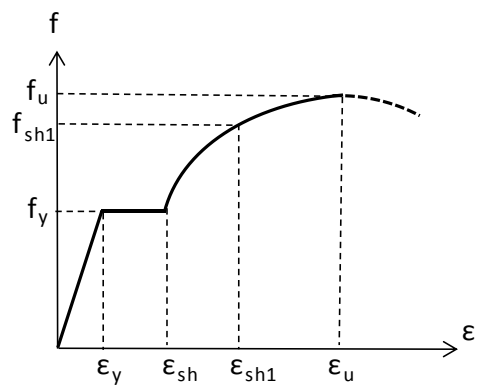

Figure 3: Monotonic stress-strain relationship of steel model [9].

\subsection{Concrete material model}

The stress-strain law for concrete proposed by $\mathrm{Lu}$ and Panagiotou [12] which is schematically presented in Figure 4 where $f_{c}^{\prime}$ is the compressive strength at $\varepsilon_{0}=0.2 \%$ strain for unconfined concrete. The initial concrete modulus is $E_{c}=5000 \sqrt{f_{c}^{\prime}}(\mathrm{MPa})$. Ultimate strain $\left(\varepsilon_{u}\right)$ of concrete is adjusted by accounting for the mesh-size effects due to the procedure outlined by Lu and Panagiotou [15].

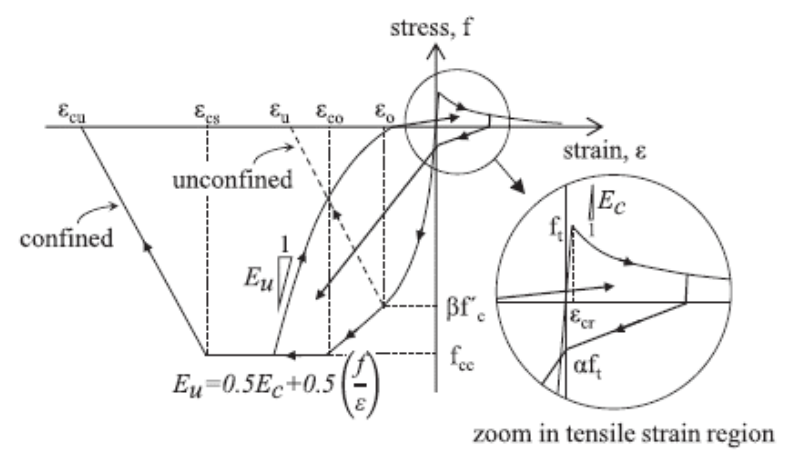

Figure 4: Stress-strain law for concrete material model [9].

For horizontal and vertical concrete truss elements, tensile strength is $f_{t}=0.33 \sqrt{f_{c}^{\prime}}(\mathrm{MPa})$ with a softening portion in accordance with tension stiffening based on Eq. (3) by Stevens et al. [21]:

$$
\begin{gathered}
f=f_{t}\left[(1-M) e^{-\lambda_{t}\left(\varepsilon-\varepsilon_{c r}\right)}+M\right] \\
M=C_{t} \frac{\rho_{l}}{d_{b}} \\
\lambda_{t}=\frac{540}{\sqrt{M}}
\end{gathered}
$$

Where $\rho_{l}$ is steel ratio in the horizontal and vertical truss elements, $M$ is tension stiffening parameter, $d_{b}$ is rebar diameter and $C_{t}=75 \mathrm{~mm}$.

The concrete material model for the diagonal elements considers for the reduction of compressive strength due to transverse strains described by Vecchio and Collins [22]. Compressive stresses are multiplied by a reduction coefficient $(\beta)$ at each analysis step based on calculated transverse strains using fictitious strain gauge elements. Figure 5 shows the relation between stress reduction factor, $\beta$, and normal strain, $\varepsilon_{n}$. The values of $\beta_{\text {int }}=0.3$ and $\beta_{\text {res }}=0.1$ are considered for analyses.

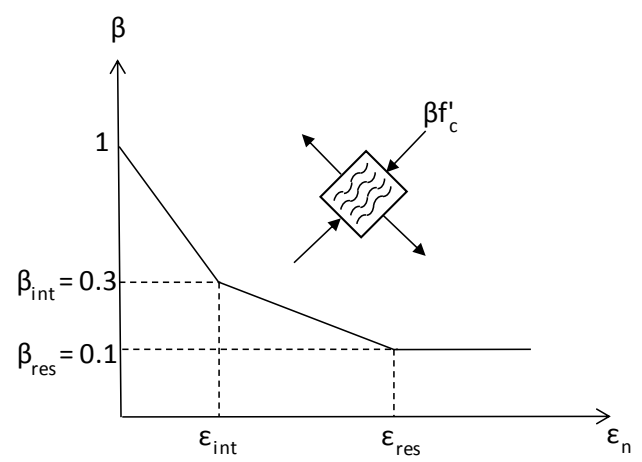

Figure 5: Relation between reduction factor and normal strain [9].

\section{Buckling length of reinforcing bars}

Reinforcing bars idealized as fixed ends between subsequent stirrups are considered to have local buckling mode. However, buckling length can span within a few times stirrup spacing as a result of global buckling. Dhakal and Maekawa [20] proposed the determination of buckling length of longitudinal rebars for RC rectangular sections based on energy method. Determination of buckling mode and buckling length of reinforcing bars are summarized in Figure 6.

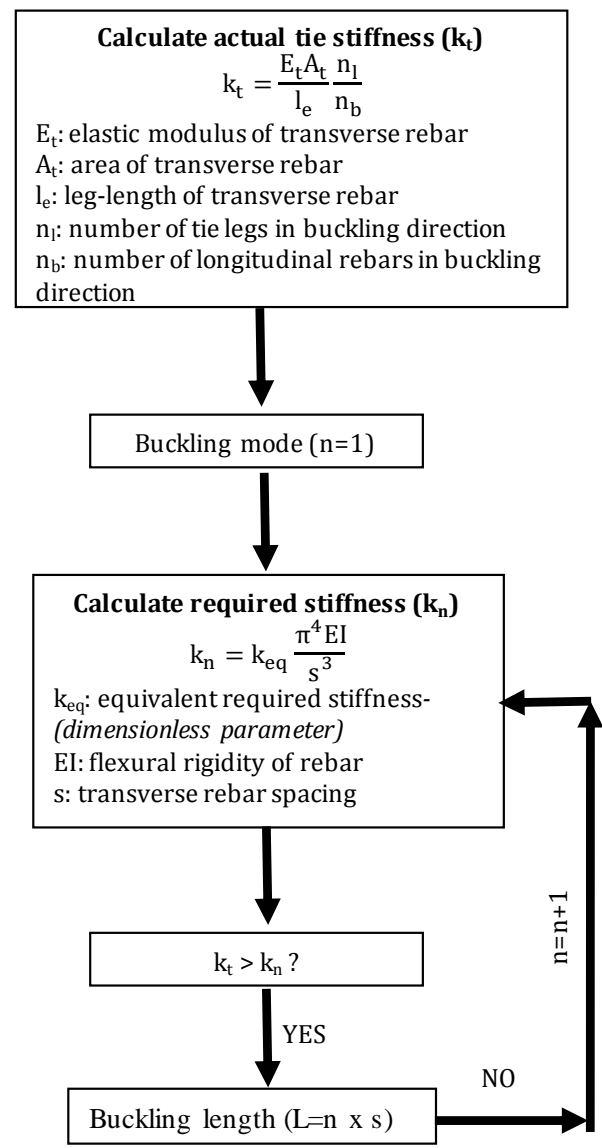

Figure 6: Determination of buckling mode and buckling length for longitudinal rebars [adapted from 20]. 


\section{Case Study}

\subsection{Nonlinear truss model}

Nonlinear truss modeling approach is verified by experimental test results of one RC beam tested by Visnjic et al. [23]. Visnjic et al. studied [23] experimental cyclic behavior of two large RC beams, namely Beam\#1 and Beam\#2 with various hoop spacing subjected to vertical tip displacements. Section reinforcing details of Beam \#2 with reduced hoop spacing is shown in Figure 7. The beam had longitudinal reinforcing bars with a longitudinal steel ratio $\rho_{l, t}=0.56 \%$ at the top and bottom of the beam. The volumetric confinement reinforcement ratio was $\rho_{s}=0.51 \%$ for Beam\#2. Concrete and reinforcing steel stress (MPa) and strain material test results are given in Table 1.

Table 1. Material properties of Beam\#2 specimen.

\begin{tabular}{ccccccccc}
\hline \multicolumn{3}{c}{ Concrete } & \multicolumn{6}{c}{ Reinforcing Steel } \\
\hline$f_{c}{ }^{\prime}$ & $\varepsilon_{0}$ & $f_{t}$ & & $f_{y}$ & $f_{u}$ & $\varepsilon_{y}$ & $\varepsilon_{s h}$ & $\varepsilon_{u}$ \\
42 & $0.3 \%$ & 2.14 & $\# 5$ & 455 & 706 & $0.23 \%$ & - & $17 \%$ \\
& & & $\# 11$ & 503 & 685 & $0.3 \%$ & $1.1 \%$ & $23 \%$ \\
\hline
\end{tabular}
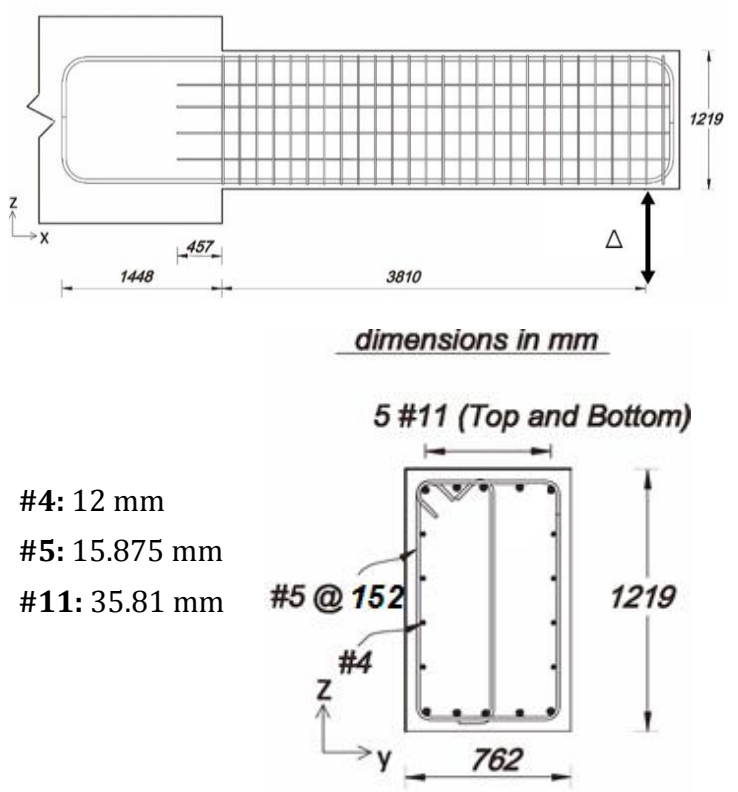

Figure 7: Geometry and reinforcing details of Beam\#2 specimen [23].

The drift ratio $\theta$ is defined as $\Delta / L$, where $\Delta$ is the vertical displacement and $L$ is the shear span between the support and the applied load. During the test, damages due to flexural deformations including buckling of rebars were observed. For Beam\#2, the initiation and increase of buckling were reported at $\theta=2.9 \%$ and $3.9 \%$ drift ratios, respectively. Following that, excessive buckling of the bottom rebar was observed during the cycle at $\theta=5.4 \%$.

Nonlinear truss models M1 and M2 accounting for the mesh size effects are developed and presented in Figure 8. Inclination angle of diagonal elements are considered as $43^{\circ}$. Top and bottom horizontal concrete and steel $\left(\boldsymbol{A}_{c h 1}, \boldsymbol{A}_{s h 1}\right)$, inner horizontal concrete and steel $\left(\boldsymbol{A}_{\boldsymbol{c h} 2}, \boldsymbol{A}_{\boldsymbol{s h} 2}\right)$, vertical concrete and steel $\left(\boldsymbol{A}_{c v}, \boldsymbol{A}_{s v}\right)$ and diagonal $\left(\boldsymbol{A}_{\boldsymbol{d}}\right)$ truss element areas of truss models are shown in Table 2. Truss element lengths $\left(\boldsymbol{L}_{\boldsymbol{s} p}\right)$ were calculated as $13 \boldsymbol{d}_{\boldsymbol{b l}}$ and $15 \boldsymbol{d}_{\boldsymbol{b w}}$, where $\boldsymbol{d}_{\boldsymbol{b l}}(35.8 \mathrm{~mm})$ and $\boldsymbol{d}_{\boldsymbol{b} \boldsymbol{w}}(12.7 \mathrm{~mm})$ are longitudinal and web reinforcement diameters, respectively.

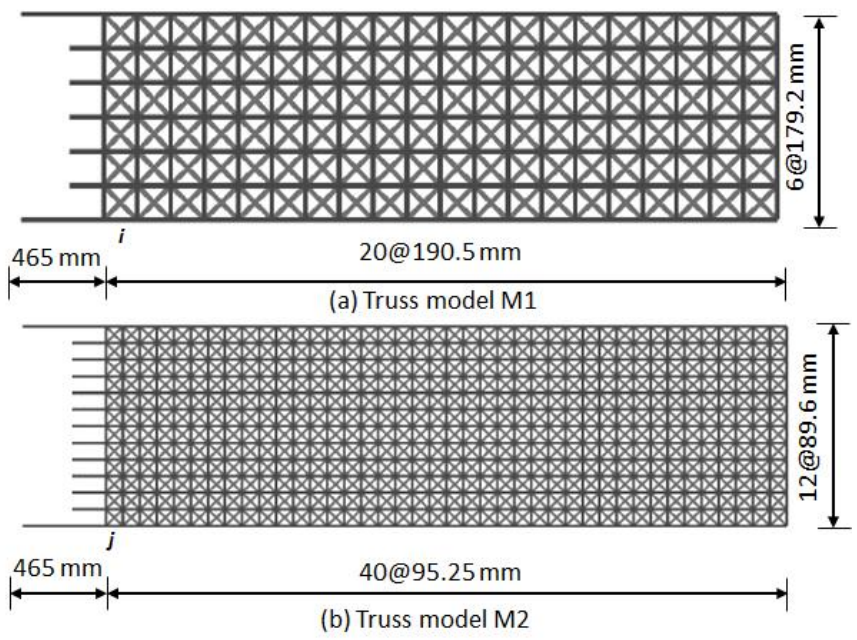

Figure 8: Nonlinear truss models for Beam\#2 specimen.

Table 2: Vertical, horizontal and diagonal truss element areas.

\begin{tabular}{ccc}
\hline $\mathrm{A}\left(\mathrm{mm}^{2}\right)$ & $\mathrm{M} 1$ & $\mathrm{M} 2$ \\
\hline $\boldsymbol{A}_{\boldsymbol{c h} \mathbf{1}}$ & 68279 & 34138 \\
$\boldsymbol{A}_{\boldsymbol{s h} \mathbf{1}}$ & 5036 & 5036 \\
$\boldsymbol{A}_{\boldsymbol{c h} 2}$ & 136558 & 68275 \\
$A_{s h 2}$ & 203 & 94 \\
$A_{c v}$ & 145161 & 72580.5 \\
$A_{s v}$ & 428.5 & 219.5 \\
$A_{d}$ & 99463 & 49730 \\
\hline
\end{tabular}

Buckling mode $(n)$ and corresponding buckling length $\left(L_{b}\right)$ of reinforcing bars are computed using the procedure outlined in [20] as $n=4$ and $L_{b}=608 \mathrm{~mm}$, respectively. Inelastic material model including buckling is assigned to steel truss elements representing longitudinal rebars within the buckling length. For this purpose, slenderness ratio $\left(L_{b} / d_{b l}\right)$ calculated as 17 is assigned to material models in M1 and M2 truss models. Besides, effect of rebar buckling on the response was studied by conducting cyclic analysis by neglecting buckling in M2 model.

\subsection{Analysis results}

OpenSees computer program [24] is used for the analyses described in this paper. The response is computed with a displacement controlled algorithm. Newton with Initial Tangent is used in the solution algorithms. For each iteration, the residual of error was computed using Energy Increment, and the relative tolerance was equal to $10^{-3}$.

Applied moment- drift ratio of measured and numerical cyclic responses of truss models are compared in Figure 9. M1 model computed a significant strength degradation caused by diagonal concrete crushing at $5.8 \%$ drift ratio. However, M2 model showed strength degradation due to rebar buckling at $4 \%$ drift ratio. Applied force histories of the beam specimen and M2 model are shown in Figure 10. The computed strength when the excessive buckling was observed $(5.4 \%$ drift) was 0.84 times the experimentally measured strength. 


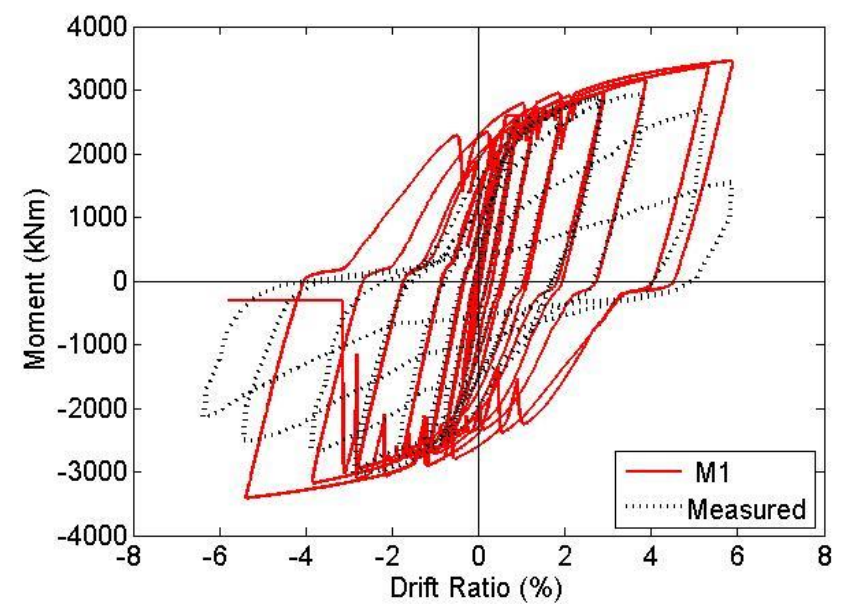

(a)

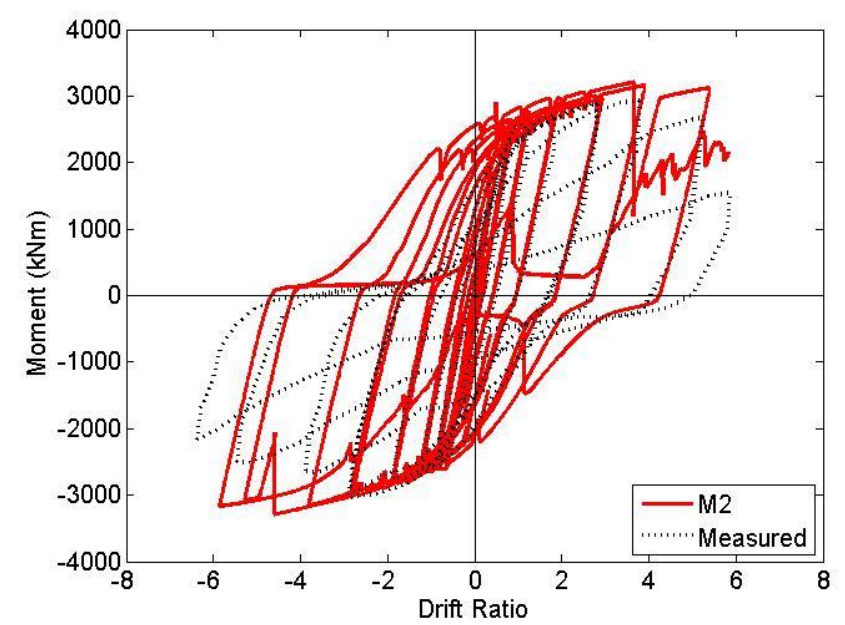

(b)

Figure 9: Comparison of measured and numerical model responses for (a) M1 and (b) M2 truss models.
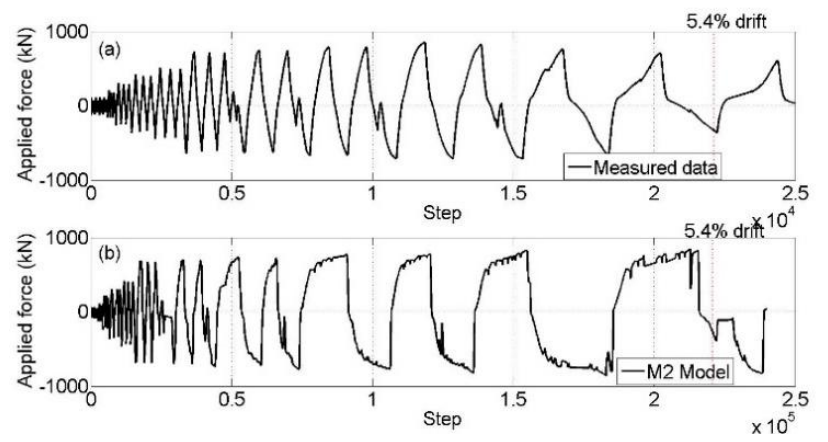

Figure 10: Comparison of (a): Measured and (b): Numerical model applied force histories.

Stress-strain history of longitudinal steel truss elements $i$ and $j$ (Figure 7) are shown in Figure 11. M1 model had an abrupt degradation due to diagonal crushing at an earlier stage and rebar strains were computed in the tensile direction. Analytical damage patterns with corresponding truss strains of truss models at initiation of strength degradation are shown in Figure 12.

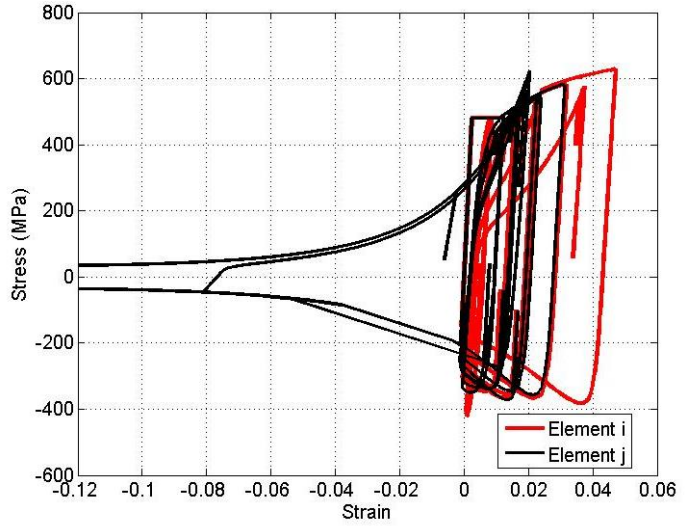

Figure 11: Stress-strain history of steel truss elements for longitudinal rebars.

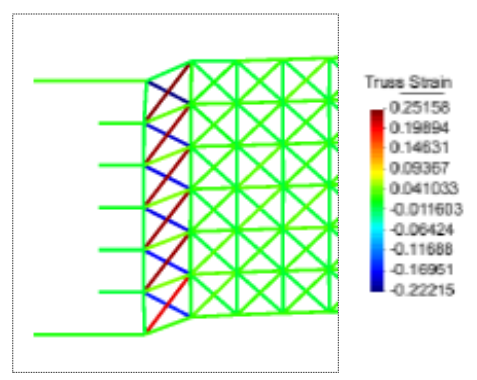

(a): Model M1.

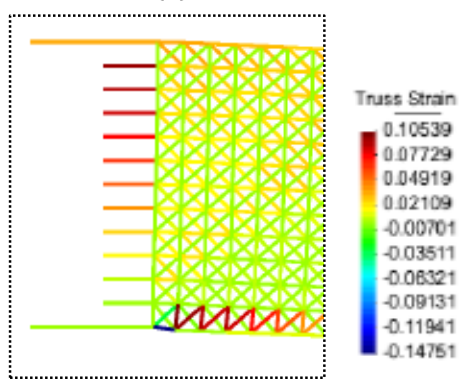

(b): Model M2.

Figure 12: Analytical damage patterns at plastic hinge region at initiation of strength degradation.

Figure 13 depicts the comparison of the cases with and without reinforcing bar buckling in M2 model. The model neglecting the rebar buckling computed larger energy dissipation.

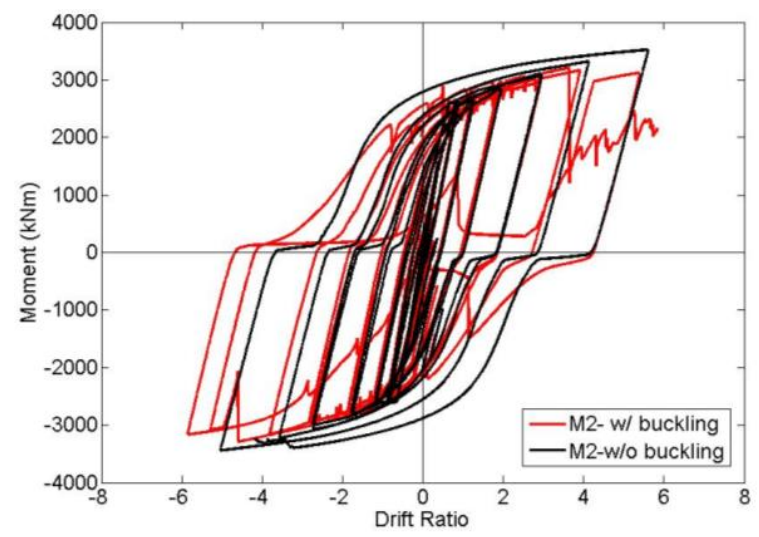

Figure 13: Comparison of M2 model with and without rebar buckling. 


\section{Conclusion}

This paper has presented an extension for a previously proposed nonlinear truss model accounting for the effect of inelastic reinforcing bar buckling in RC members. The steel material law has been combined with an existing uniaxial model for concrete and implemented in nonlinear truss models. Numerical simulation model is validated using test results of a large RC beam with reinforcing bar buckling. Mesh size effects and effect of reinforcing bar buckling on the response are investigated for the case study. M1 model computed the crushing of diagonal elements at the vicinity of the reaction block. However, M2 model with finer mesh computed strength degradation based on initiation of rebar buckling in accordance with the experimental results. Besides, the model without rebar buckling computed larger energy dissipation compared to M2 model. Further validation of the analysis approach will supply its use for the assessment of the performance of RC components and systems. Models with various mesh size for truss elements as a function of buckling length should be examined for future work.

\section{Acknowledgment}

The work presented in this paper was conducted during the visit of the author as a post-doctoral scholar to the Virginia Polytechnic Institute and State University. This visit was supported by the Scientific and Technological Research Council of Turkey (TUBITAK) 2219 Program. The author would like to thank Dr. Ioannis Koutromanos and Dr. Mohammadreza Moharrami for providing custom version of OpenSees with uniaxial steel material model including buckling. The author also wish to acknowledge Dr. Marios Panagiotou for sharing the beam test data.

\section{References}

[1] Moehle J. Seismic Design of Reinforced Concrete Buildings. New York, USA, McGraw Hill Professional 2014.

[2] Monti G, Nuti C. "Nonlinear behaviour of reinforcing bars including buckling". Journal of Structural Engineering, 118 (12), 3268-3284, 1992.

[3] Gomes A., Appleton J. "Nonlinear cyclic stress-strain relationship of reinforcing bar including buckling". Engineering Structures, 19(10), 822-826, 1997.

[4] Rodriguez ME, Botero, JC, Villa J. "Cyclic stress-strain behavior of reinforcing steel including effect of buckling". Journal of Structural Engineering, 125(6), 605-612, 1999.

[5] Zong Z, Kunnath S, Monti G. "Simulation of reinforcing bar buckling in circular reinforced concrete columns". ACI Structural Journal, 110(4), 607-616, 2013.

[6] Massone LM, Lopez EE. "Modeling of reinforcement global buckling in RC elements". Engineering Structures, 59, 484-494, 2014.

[7] Feng Y, Kowalsky MJ, Nau JM. "Finite-element method to predict reinforcing bar buckling in RC structures". Journal of Structural Engineering, 141(5), 04014147 (1-12), 2015.

[8] Kashani MM, Lowes NL, Crewe AJ, Alexander NA. "Nonlinear fibre element modelling of RC bridge piers considering inelastic buckling of reinforcement". Engineering Structures, 116, 163-177, 2016.
[9] Kim SE, Koutromanos I. "Constitutive model for reinforcing steel under cyclic loading". Journal of Structural Engineering, 142(12), 04016133, 2016.

[10] Dodd LL, Restrepo-Posada JI. "Model for predicting cyclic behavior of reinforcing steel”. ASCE Journal of Structural Engineering, 121(3), 433-445, 1995.

[11] Kim, JH, Mander JB. "Truss Modeling of Reinforced Concrete Shear-Flexure Behavior". University at Buffalo, State University of New York, USA, MCEER Report 99-0005, 1999.

[12] Miki T, Niwa J. "Nonlinear analysis of RC structural members using 3D lattice model". Journal of Advanced Concrete Technology, 2(3), 343-358, 2004.

[13] Park H, Eom T. “Truss model for nonlinear analysis of RC members subject to cyclic loading". Journal of Structural Engineering, 133(10), 1351-1363. 2007.

[14] Panagiotou M, Restrepo JI, Schoettler M, Kim G. "Nonlinear cyclic truss model for reinforced concrete walls". ACI Structural Journal, 109(2), 205-214, 2012.

[15] Lu Y, Panagiotou M. "Three-dimensional cyclic beam-truss model for non-planar reinforced concrete walls". Journal of Structural Engineering, 140(3), 04013071 (1-11), 2014.

[16] Moharrami M, Koutromanos I, Panagiotou M, Girgin SC. "Analysis of shear-dominated RC columns using the nonlinear truss analogy". Earthquake Engineering Structural Dynamics, 44(5), 677-694, 2015.

[17] Lu Yuan, Marios Panagiotou, Ioannis Koutromanos. "Three-Dimensional Beam-Truss Model for ReinforcedConcrete Walls and Slabs Subjected to Cyclic Static or Dynamic Loading" Earthquake Engineering Research Center, University of California, Berkeley, No. UCB/ PEER, $18,2014$.

[18] Zhao J, Sritharan S. "Modeling of strain penetration effects in fiber-based analysis of reinforced concrete structures". ACI Structural Journal, 96(1), 29-39, 2007.

[19] Girgin SC, Koutromanos I, Moharrami M. "Numerical simulation of reinforced concrete members with reinforcing bar buckling". 12 th International Congress on Advances on Civil Engineering, Istanbul, Turkey, 21-23 September 2016.

[20] Dhakal RP, Maekawa K. "Reinforcement stability and fracture of cover concrete in reinforced concrete members". Journal of Structural Engineering, 128(10), 1253-1262, 2002.

[21] Stevens NJ, Uzumeri SM, Collins MP, Will TG. "Constitutive model for reinforced concrete finite element analysis". ACI Structural Journal, 88(1), 49-59, 1991.

[22] Vecchio FG, Collins MP. "The modified compression field theory for reinforced concrete elements subjected to shear". Journal of the American Concrete Institute, 83(2), 219-231, 1986.

[23] Visnjic T, Antonellis G, Panagiotou M and Moehle JP. “Large reinforced concrete special moment frames under simulated seismic loading". ACI Structural Journal, 113(3), 469-480, 2016.

[24] McKenna F, Fenves GL, Scott MH, Jeremic B. “Open System for Earthquake Engineering Simulation". http://opensees.berkeley.edu, (2015). 